\title{
Frameworks for Effective Character Education Practices
}

\author{
Benfeng Yan \\ School of Philosophy, Politics and Law, Yunnan Normal University \\ Kunming, China \\ Email: ybf20055@163.com
}

\begin{abstract}
The success of attempts to promote the development of character and socioemotional competencies in students will rest on the ability to identify and then effectively implement evidence-based practices: authentically prioritizing character education in schools; strategically and intentionally promoting positive relationships among all school stakeholders; nurturing the internalization of character strengths/values/virtues resulting in intrinsic motivation; modeling character and socioemotional competencies; empowering all stakeholders to be co-owners and coauthors of the initiative; employing a developmental pedagogy. This has led to a list of $\mathbf{4 2}$ character education implementation strategies which have research evidence to support their effectiveness specifically in promoting character and socioemotional development.
\end{abstract}

Keywords: Character; character education; effective practices

\section{DEFINING CHARACTER AND CHARACTER EDUCATION}

Character education is defined as "the intentional attempt in schools to foster the development of students' psychological characteristics that motivate and enable them to act in ethical, democratic, and socially effective and productive ways" (Berkowitz, Althof, \& Bier, 2012, p. 72). It is important to note that we have long focused on the interpersonal, especially the moral, aspect of character; that is, one's motivation and capacity to do what is ethically right and socially responsible. However, character has been divided into at least four subcategories: moral, performance, intellectual, civic (Shields, 2011). character is the set of psychological characteristics that motivate and enable one to function as a moral agent, to perform optimally, to effectively pursue knowledge and intellectual flourishing, and to be an effective member of society.

\section{FRAMEWORKS FOR IDENTIFYING AND IMPLEMENTING EFFECTIVE PRACTICES}

By "framework" we mean a conceptual system, a set of ideas, that has links to a research base but is more than just a list of "effective practices." It is a higher order way of thinking about discrete effective practices that sets forth general principles - "big ideas"- that in turn enable us to cluster effective practices, provide broad guidance for implementation, and identify where more research is needed in order to clarify our understanding of what makes for optimally effective character education. Character.org, the predominant character education organization, has used as its flagship guidelines The
Eleven Principles of Effective Character Education (11P) since at least 1996 (www.character.org). CASEL has offered its SAFE criteria for effective practice, encompassing four key principles: Sequenced activities within a coordinate curriculum; Active pedagogy aimed as mastery of SEL skills; Focused component of the school that targets SEL skills; Explicit targeting of specific SEL skills. That National School Climate Center (www.schoolclimate.org) offers many such frameworks for understanding school climate. A different framework, one focused on meeting basic psychological needs, comes from self-determination theory (Deci \& Ryan, 2002). Self-determination theory posits three fundamental human psychological needs-for autonomy, belonging and competence - and maintains that effective education can happen only when schools target and effectively fulfill these needs. From an educational perspective, this should lead to a consideration of what educational strategies are necessary to promote the fulfillment of these needs. For example, Reeve and Halusic (2009) have articulated the characteristics of an "autonomy-supportive classroom": "take the students' perspective, display patience to allow time for learning, nurture inner motivation resources, provide explanatory rationales, rely on noncontrolling language, and acknowledge and accept expressions of negative affect" (p. 145). Still another framework, which is called PRIME (Berkowitz, 2009; Berkowitz \& Bier, 2014; Berkowitz \& Bustamante, 2013), an acronym for five principles of effective character education: Prioritizing character education as central to the school's (or classroom's) mission and purpose; promoting positive Relationships among all school stakeholders; fostering the internalization of positive values and virtues through Intrinsic motivational strategies; Modeling character by adults; emphasizing a pedagogy of Empowerment which gives authentic voice to all stakeholders.

In this article, we identified all the effective practices in all the sources we examined and then made a master list of them. We found we could categorize almost all of these evidence-based strategies into one of the five concepts of PRIME. We added a sixth category (developmental pedagogy) to incorporate the rest of the strategies that did not easily fit PRIME; in effect changing PRIME to PRIMED.

\section{A. Prioritization.}

Character education needs to be an authentic priority in the school. This includes being central to seminal statements such as mission and vision statements. It also includes leadership that has both the capacity and 
competency to lead a school to effective implementation as well as the inclination to do so. It also requires an investment in the professional development of all key stakeholders (Berkowitz \& Bier, 2005; Darling-Hammond, 2002). A shared language and set of values that are explicit and, ideally, consensual should undergird and frame the initiative. Schools and classrooms need to intentionally foster the development of climates that feel safe to students, that care for and include all, and that strive for justice in discipline and the distribution of resources.

The prioritization strategies identified in this research are grouped into five subcategories: (1) rhetorical emphasis; (2) allocation of resources; (3) school and classroom climate; (4) schoolwide structures; (5) leadership.

\section{B. Relationships.}

The strategic and intentional nurturing of relationships is foundational for effective practice. School structures and schedules that are dedicated to relationship building must be intentionally implemented to support the formation of such relationships. All stakeholders and their interrelationships should be included in this relational focus. Schools should connect to and leverage non-school community members and organizations. This includes parent involvement, but also includes local government, local business, law enforcement, community organizations, et cetera (Darling-Hammond, 2002). The relationship-supportive strategies identified in this review are clustered into two subcategories: (1) within school; (2) beyond school.

\section{Intrinsic Motivation (Internalization)}

Strategies should be selected for their power to lead to the authentic internalization of the specific values and virtues that the initiative is designed to foster, as well as authentic personal commitment to the socioemotional competencies being targeted. Ultimately, strategies that support intrinsic motivation, the development of a prosocial identity, and virtue should be identified and selected for implementation. Internalization strategies identified in this review are clustered into three subcategories: (1) behavior management strategies; (2) strategies for self-growth; (3); opportunities to serve others.

\section{Role Models.}

All adults who exist in the school environment need to model what they want students to be and do. Students need to also be exposed to other role models, especially including exemplars and covering all aspects of good character-performance, civic, intellectual, civic and moral character. Such models can be older students, community members, historical figures, and fictional characters in literature.

\section{E. Pedagogy of Empowerment.}

Schools need to flatten their governance structures and honor the voices of all stakeholders by sharing power and institutionalizing structures and practices that are more democratic and less authoritarian and hierarchical. In essence, this is a matter of respect for personhood and meeting the fundamental autonomy needs of all school members, while also serving citizenship development in a democratic society.

\section{F. Developmental Pedagogy.}

Students' needs should be understood and met, particularly through the strategies implemented. These include challenge, autonomy, belonging, competence, and relevance. The developmental pedagogy identified in this research is grouped into three subcategories: (1) direct teaching of character; (2) Expectations for student development; (3) Opportunities to practice and master new competencies.

\section{III.SPECIFIC IMPLEMENTATION STRATEGIES FOR THE SIX PRINCIPLES}

\section{A. Prioritization}

Prioritization is about focusing authentically on nurturing the development of character both in students and in the school (or classroom) as an organization. It is an organizational analogy to the idea of individual noble purpose. There are five interrelated ways to manifest the priority of character education in a school, which may be depicted as five subcategories of the principle of prioritization.

\section{1) Rhetoric}

One important way to prioritize character education and development is through the language of the school. Having a shared or common language is often recognized and implemented in schools to varying degrees. This is most typically a set of core values, virtues, socioemotional competencies, or character strengths, as suggested in the first principle of the Character. Often however, such words are, in actual practice, merely "words on a wall" and have little impact on the actual functioning of the school. Effective practice includes wide understanding of the words, operational definitions, behavioral anchoring, and even rubrics. Then the words are used widely and incorporated throughout school functioning; e.g., discipline, academic curricula.

2) Allocation of resources.

There are three strategies for prioritization through the allocation of resources. (1) the allocation of resources by school leadership is essential to the effective promotion of socioemotional competencies in students. (2) One specific place to allocate resources is to the professional development of staff in ways that support the competency to engage in effective character education. (3) One specific way to support staff professional development and effective implementation is to intentionally foster a learning community, or, a professional ethical learning community.

3) School Climate.

Character development is a product of the social organization of the classroom and/or school. Five specific strategies of relevance to school climate are as following: (1) the need for a clear schoolwide culture or focus on character education. (2) Trust in teachers supports 
effective character education. (3) An environment that is psychologically and physically safe, and is perceived as such by school members. (4) The promotion of caring schools and classrooms as supportive of character development and socioemotional competencies. (5) Lastly, assessing school climate is part of Character.

\section{4) Structural prioritization.}

Schools can be restructured in ways that increase the presence and prioritization of character education. Research supports five different ways of structuring for character education. (1) Making character education comprehensive, so that it impacts all aspects of development and is integrated in all aspects of the school. (2) Having clear rules that are widely known. (3) Schools collaborating for character education. (4) Making character and character education visible and salient through displays and awards. (5) Assessing character and giving students feedback on their behavior.

\section{5) Leadership.}

Leadership is one area of practice. leadership is included as a prioritization strategy and school leadership is critical in promoting character development. school leaders need to understand character, character development and character education, be instructional leaders for it, model good character, and empower all stakeholders in the school to share in the responsibility of effectively fostering character and socioemotional development in students.

\section{B. Relationships}

Relationships are foundational to good schools and the promotion of character and socioemotional development. It is worth noting that relationships will not happen widely, but rather selectively, if they are not a strategic goal of the school, and hence strategically built into school processes, policies, and structures.

1) Within school relationship strategies.

Because relationships are so foundational, five different approaches are revealed to promoting positive relationships within the school. (1) The promotion of healthy relationships. (2) There should be an emphasis on pedagogical strategies that require peer interaction; e.g., cooperative learning, class meetings, peer tutoring, moral dilemma discussion, et cetera. (3) The use of an effective peer conflict resolution program. (4) Teachers' nurturing relationships with and attitudes toward students are effective in promoting character and socioemotional development. (5) Nurturing the development of relationship skills.

2) Beyond school.

One of the more commonly reported strategies is the promotion of school to family and school to community relationships.

\section{Intrinsic Motivation (Internalization of Character)}

Ultimately, the goal of character education is for children and adolescents to become good people, to develop into and act effectively as agents for good in the world. Hence this is as much about being people of character as it is about acting good. Both are essential. This is where so many schools go awry-by relying on strategies that shape behavior, but are not equally effective in nurturing the inner character that is the source of virtuous behavior. The goal of authentic character education should be the internalization of values and virtues that motivate and guide one's behavior, along with the socioemotional competencies to enact those internalized characteristics. character is defined as having a cognitive (knowledge, reasoning) component, an affective/ motivational component, and a behavioral component. It is the affective/motivational component that requires internalization that in turn leads to intrinsic motivation to act out of those values and virtues. The promotion of such intrinsic motivation requires a specific set of strategies. Therefore the strategies for promoting intrinsic motivation may be clustered into three subcategories: management of student behavior; promotion of personal growth; service to others.

1) Management of student behavior.

One of the great challenges of schooling is to help students behave in ways that are safe, prosocial, and conducive to learning. The range of options is wide. Doing so in order to promote intrinsic motivation, however, has been linked to a specific set of practices. Four strategies for managing behavior are found in this article. (1) Developmental discipline. How undesirable behavior is understood and responded to should align with the practices of developmental discipline. It should be done to promote rather than undermine relationships. It should be construed and approached as an opportunity to nurture the long-term positive development of the child, including to enhance and practice healthy SEL competencies. It should be done in ways that empower the child to take responsibility for his/her actions and to repair the damage those actions caused. It should rely on ensuring that students understand why their behavior is inappropriate and how it has impacted others and particularly their emotions. (2) The use of induction to foster empathy. (3) Praising effort and not ability. (4) The promotion of reflection (especially about morality and character).

2) Promotion of personal growth.

Another way to foster the internalization of character strengths and increasing the intrinsic motivation to be a moral agent is to specifically target strategies that promote personal growth. (1) Having a challenging and meaningful academic curriculum. (2) Providing opportunities to redo one's efforts, both academic and behavioral. (3) Helping students identify and set goals for themselves. This can include reflecting on one's ideal self (future self, possible self) and crafting a plan to move toward it.

\section{3) Service to others.}

There should be many opportunities for all students to serve others. This can be done through formal roles in the school, such as student government. It can be done through peer relationships, such as peer tutoring or teaching advisory class lessons. Two strategies. (1) Providing opportunities for moral action is one of the most frequently identified strategies. (2) Serving others through community service or service learning.

\section{Modeling}


In the parenting literature, it is well established that parents need to not only use parenting strategies that foster specific character outcomes, but they need also to model those outcomes. This is true as well for educators, but it is often a difficult pill to swallow, many examples of evidence for the necessity for educators are clustered into two strategies.

\section{1) Role modeling/mentoring.}

Students should be provided with ample models of character. This most centrally includes the adults in the school (and oftentimes older students as well). Role modeling and mentoring is identified as an effective practice in fostering the development of character and socioemotional competencies.

2) Studying role models.

Students can also learn from role models beyond the school, such as figures in society and history, and figures in literature, but individuals in the local community too.

\section{E. Pedagogy of Empowerment}

Hierarchical and authoritarian school practices should be transformed to incorporate appropriate opportunities for student voice. This also aligns with the autonomy-supportive classroom model of self-determination theory. There were four specific strategies that support the promotion of empowerment. (1) General empowerment and collaboration. (2) Shared leadership. (3) Creating democratic classrooms. (4) Being fair to and respectful of students.

\section{F. Developmental Pedagogy.}

All above seem to focus on the direct promotion of positive development. Hence this paper has generated a sixth principle for the PRIME model and turning it into PRIMED. In turn, the six strategies have been clustered into three subcategories: teaching character; expectations for growth; practice.

\section{1) Teaching character.}

There are three strategies aligned with teaching character and socioemotional development. (1) The direct and targeted teaching of character (2) Direct teaching of socioemotional competencies. (3) Providing opportunities for students to practice and master these competencies, often through role-playing.

\section{2) Expectations for growth/development.}

There were two strategies identified that target the promotion of general development or growth. (1) In alignment with much research on both parenting and education, setting high expectations (for academics and/or character) is identified. (2) Mental contrasting effectively promotes persistence. Mental Contrasting in combination with Implementation Intention is a strategy that asks students to compare the idea of a desired future state with obstacles that they envision might impede their progress toward that state and to construct if-then scenarios for how they might overcome each obstacle.

\section{3) Practice.}

The use of the specific developmental strategy of practicing desired competencies and strengths, including the particular use of role-playing, was identified by many researchers.

\section{CONCLUSIONS}

The success of attempts to promote the development of character and socioemotional competencies in students will rest on the ability to identify and then effectively implement evidence-based practices: authentically prioritizing character education in schools; strategically and intentionally promoting positive relationships among all school stakeholders; nurturing the internalization of character strengths/values/virtues resulting in intrinsic motivation; modeling character and socioemotional competencies; empowering all stakeholders to be co-owners and coauthors of the initiative; employing a developmental pedagogy. This has led to a list of 42 character education implementation strategies which have research evidence to support their effectiveness specifically in promoting character and socioemotional development.

\section{References}

[1] Berkowitz, M. W., Althof, W., \& Bier, M. C. (2012). The practice of pro-social education. In P. Brown, M. Corrigan, \& A. Higgins-D'Alessandro (Eds.), The handbook of prosocial education (Vol. 1, pp. 71-90). Lanham MD: Rowman \& Littlefield.

[2] Shields, D. L. (2011, May). Character as the aim of education. Phi Delta Kappan, 92, 48-53.

[3] Deci, E. L., \& Ryan, R. M. (2002). An overview of self-determination theory handbook of self determination research. Rochester, NY: University of Rochester Press.

[4] Reeve, J. M., \& Halusic, M. (2009). How K-12 teachers can put self-determination theory principles into practice. Theory and Research in Education, 7, 145-154.

[5] Berkowitz, M. W. (2009). Teaching in your PRIME. In D. Streight (Ed.), Good things to do: Expert suggestions for fostering goodness in kids (pp. 9-14). Portland, OR: Council for Spiritual and Ethical Education Publications.

[6] Berkowitz,M. W., \& Bier, M. C. (2014). Research-based fundamentals of the effective promotion of character development in schools. In L. Nucci, D. Narvaez, \& T. Krettenauer (Eds.), Handbook on moral and character education (pp. 248-260). New York, NY: Routledge.

[7] Berkowitz, M. W., \& Bustamante, A. (2013). Using research to set priorities for character education in schools: A global perspective. Korean Journal of Educational Policy, 2013, 7-20.

[8] Berkowitz, M. W., \& Bier, M. C. (2005). What works in character education: A research-driven guide for educators. Washington, DC: Character Education Partnership.

[9] Darling-Hammond, L. (2002). Re-designing high schools: What matters and what works. Stanford CA: Stanford Redesign Network.

[10] Marvin W. Berkowitz and Melinda C. Bier,"Toward a science of character education", Journal of Character Education, Vol. 13(1), 2017, pp. 33-51. 